\title{
"We are hope, you are the eternal khan." Authoritarian regimes and protest opportunities in Central Asia
}

\begin{abstract}
The aim of this text is to analyze the political determinants deciding the functioning of the opposition and contentious practices in undemocratic regimes of Central Asia. The analysis is based on five countries with varying degrees of authoritarianism and allows us to trace the relations between the political context and protest activities, which in the different forms depending on the local structure of power, have taken place in all five of the countries in the region. The example of Central Asian countries supports the ideas about the patterns of protest being dependent on the type of political regime. Moreover, one may observe the growing role of Internet activism in informing and mobilizing public opinion, encouraging the expression of opinion, collecting various resources, provoking support, and building a network of relations within the civil society. Finally, the research shows that the more repressive the regime is, the smaller the opportunity for using traditional forms of protest, and in extreme cases contestation is limited to the Internet.
\end{abstract}

Key words: Central Asia, authoritarianism, protests, contention, repression, opposition

\section{Introduction}

O ne important finding in contemporary research on contentious politics is the thesis that social discontent and grievances are not sufficient reason for the outbreak of social or individual acts of protest. The political process theory points to the importance of contextual factors in the ability to act. The category of political opportunity structures defines the impact of the political environment on the potential of social movements for mobilization, advancing particular claims, the use of specific strategies and tactics, or the impact on politics and the formulation of public policies (Meyer, 2004, p. 126). These findings are particularly important in non-democratic countries which systematically violate civil rights and resort to a variety of measures to prevent alternation of power (see: Table 1). Due to the limited ability of the opposition to operate, the influence of political factors on patterns of contentious behavior is particularly evident. The authorities in those countries perceive the very opportunity of political protest as an existential threat to the political and economic system; something that has to be dealt with using brutal methods (Goldston, Tilly, 2001).

The aim of this text is to analyze the political determinants deciding the functioning of the opposition and contentious practices in undemocratic regimes of Central Asia. The analysis is based on five countries with varying degrees of authoritarianism and allows us to trace the relations between the political context and protest activities, which in the different forms depending on the local structure of power, have taken place in all five 
of the countries in the region. Characteristically, social protests usually failed to bring change. The only exception was Kyrgyzstan, where the regime had been overthrown twice, in 2005 and 2010. The example of Central Asian countries supports the Ch. Tilly theory about the patterns of protest being dependent on the type of political regime (Tilly, 2006). Moreover, one may observe the growing role of Internet activism in informing and mobilizing public opinion, encouraging the expression of opinion, collecting various resources (material, cultural, symbolic, etc.), provoking support, and building a network of relations within the civil society (Van De Donk, Loader, Nixon, Rucht, 2004). This research shows that the more repressive the regime is, the smaller the opportunity for using traditional forms of protest (see: Table 1), and in extreme cases contestation is limited to the Internet.

Protest is understood as the expression of a negative reaction to the prevailing socio-political situation, and may assume the form of rallies, demonstrations, marches, pickets, strikes, hunger strikes, petitions, complaints, appeals to the justice system, sabotage of government decisions, roadblocks, seizure of land or other forms of civil disobedience, terrorism, extremist actions, and armed struggle. It also takes into account contestation via the Internet, which has created opportunities for a more secure form of participation in anti-government online interactions (such as joining communities, participating in online discussions, creating, sharing and receiving various contents, etc.). In this sense, it is a broader concept than contentious politics understood as 'claim making' activities leading to coordinated collective actions based on interests and programs which address or target the government (Tilly, Tarrow, 2015, p. 7). The idea of contestation employed in the paper takes into account J. Scott's concept of "the weapons of the weak." It refers to less spectacular and seemingly insignificant acts of resistance undertaken on a daily basis in conditions of a strong asymmetry of power (Scott, 1985). This is particularly appropriate in the case of the most aggressive regimes, where the possibility of protest is limited to a minimum, and the authorities perceive any activity independent of the state as an act of opposition which has to be repressed.

The analysis is based on the analytical framework developed deductively on the basis of academic literature on authoritarian states. Main method is the qualitative analysis which focuses itself on the dimensions selected in the framework. Additionally, the paper is based on desktop research of the literature on the topic. The time period covered in this study covers 2010-2018. It starts with the April revolution and ethnic conflict in Kyrgyzstan. They were the main events affecting not only internal but also regional politics. The text is based on sources in various languages: Kyrgyz, Kazakh, Uzbek, Turkmen, Russian and English. Among the analyzed sources are: legal acts, results of sociological research, reports from governmental and non-governmental organizations, as well as audiovisual media materials, websites, blogs, interviews, speeches and artistic performances. Fieldwork in Kazakhstan on 2016 and 2018 and interviews with local political actors were conducted between 2016 and 2018. The interviews were also conducted in Kyrgyzstan, Kazakhstan, Russia and Poland and are anonymised. They constitute extremely important sources of information, being not only of a complementary nature, but also helping to verify knowledge obtained from other sources. 
Characteristics of authoritarian systems in Central Asian countries

\begin{tabular}{|c|c|c|c|c|c|}
\hline $\begin{array}{l}\text { Dimensions of } \\
\text { opportunity } \\
\text { structures }\end{array}$ & Turkmenistan & Uzbekistan & Tajikistan & Kazakhstan & Kyrgyzstan \\
\hline $\begin{array}{l}\text { Political rights } \\
\text { and civil liber- } \\
\text { ties* }\end{array}$ & $\begin{array}{l}\text { Worst of the } \\
\text { Worst }\end{array}$ & $\begin{array}{l}\text { Worst of the } \\
\text { Worst }\end{array}$ & Not Free & Not Free & Partly Free \\
\hline $\begin{array}{l}\text { Opposition politi- } \\
\text { cal parties }\end{array}$ & Did not exist & Prohibited & $\begin{array}{l}\text { Prohibited or } \\
\text { marginalised }\end{array}$ & $\begin{array}{l}\text { Prohibited or } \\
\text { marginalised }\end{array}$ & Yes \\
\hline $\begin{array}{l}\text { Opposition repre- } \\
\text { sentatives }\end{array}$ & $\begin{array}{l}\text { Physically } \\
\text { liquidated, } \\
\text { imprisoned or } \\
\text { in exile }\end{array}$ & $\begin{array}{l}\text { Physically } \\
\text { liquidated, } \\
\text { imprisoned or } \\
\text { in exile }\end{array}$ & \begin{tabular}{|l|} 
Physically \\
liq-uidated, \\
impris-oned, \\
margina-lised or \\
in exile
\end{tabular} & \begin{tabular}{|l|} 
Physically liqui- \\
dated, imprisoned, \\
marginalized, or in \\
exile.
\end{tabular} & $\begin{array}{l}\text { Selective repres- } \\
\text { sion }\end{array}$ \\
\hline $\begin{array}{l}\text { State of civil } \\
\text { society }\end{array}$ & $\begin{array}{l}\text { Depoliticiza- } \\
\text { tion and apathy }\end{array}$ & $\begin{array}{l}\text { Depoliticiza- } \\
\text { tion and apathy }\end{array}$ & $\begin{array}{l}\text { Depoliticization } \\
\text { and apathy }\end{array}$ & $\begin{array}{l}\text { Depoliticization } \\
\text { and apathy }\end{array}$ & $\begin{array}{l}\text { Politicization and } \\
\text { mobilization }\end{array}$ \\
\hline $\begin{array}{l}\text { Entry into and } \\
\text { exit from the } \\
\text { country }\end{array}$ & Very difficult & Difficult & Restricted & $\begin{array}{l}\text { Restricted to } \\
\text { certain cases }\end{array}$ & $\begin{array}{l}\text { Restricted to } \\
\text { certain cases }\end{array}$ \\
\hline $\begin{array}{l}\text { Freedom of the } \\
\text { media }\end{array}$ & None & None & None & Strong constraints & Weak constraints \\
\hline $\begin{array}{l}\text { Freedom on the } \\
\text { Internet }\end{array}$ & Not Free & Not Free & Not Free & Not Free & Partly Free \\
\hline Internet access & $\begin{array}{l}\text { Very difficult } \\
\text { access }\end{array}$ & Difficult access & $\begin{array}{l}\text { Partially ob- } \\
\text { structed access }\end{array}$ & $\begin{array}{l}\text { Point barriers to } \\
\text { access }\end{array}$ & $\begin{array}{l}\text { Straightforward } \\
\text { access }\end{array}$ \\
\hline $\begin{array}{l}\text { Reaction of the } \\
\text { authorities to } \\
\text { contestation and } \\
\text { resistance }\end{array}$ & No tolerance & No tolerance & Partial tolerance & \begin{tabular}{|l|} 
Prevalence of \\
formal/informal \\
repression, indif- \\
ference, incidental \\
cases of positive \\
reaction
\end{tabular} & $\begin{array}{l}\text { Mostly indiffer- } \\
\text { ence / } \\
\text { cases of co- } \\
\text { option }\end{array}$ \\
\hline $\begin{array}{l}\text { Repression and } \\
\text { harassment of } \\
\text { family members }\end{array}$ & Yes & Yes & Yes & Yes & Selective \\
\hline $\begin{array}{l}\text { Repressive psy- } \\
\text { chiatry }\end{array}$ & Yes & Yes & None & Yes & None \\
\hline $\begin{array}{l}\text { Concentration } \\
\text { camps }\end{array}$ & Yes & Yes & None & None & None \\
\hline $\begin{array}{l}\text { Forced labor (in- } \\
\text { cluding children) }\end{array}$ & Yes & Yes & None & None & None \\
\hline
\end{tabular}

* According to the 2017 Freedom House Worst of the Worst ranking, Uzbekistan and Turkmenistan joined North Korea as the countries with the worst results in terms of political rights and civil liberties (see Freedom House, 2018a).

** Since 2015, Human Rights Watch expert Mira Ritman has been banned from entering Kyrgyzstan. In 2009 and 2017, an entry ban was placed on Vitaly Ponomarev, head of the Central Asian program of the Memorial Human Rights Centre (Кожекова, 2017).

Source: Own study based on conversations with Central Asian activists in 2016-2018 and data: NGO Kazakhstan International Bureau for Human Rights and Rule Of Law; Freedom House, 2018a, 2018b, 2018c; International Partnership for Human Rights, 2018. 
Kyrgyzstan stands out among the Central Asian countries that represent different degrees of authoritarianism. It is the only state in the region where the regime was toppled as a result of social protests (twice: in 2005 and 2010). It is also the only country in the region with the principle of a single presidential term, introduced in 2010. Accordingly, President Roza Otunbaeva (2010-2011) and President Almazbek Atambaev (2011-2017) conceded their mandates at the end of their terms. In 2017, Sooronbay Jeenbekov won the presidential elections, and the former President A. Atambaev became the head of the legal opposition.

In the opinion of local political actors (conversations from 2016-2018), the cyclical change of power has ensured civil liberties such as free media, civil society organizations, and a political opposition. However, Kyrgyzstan is still a country which combines democratic and authoritarian elements, with highly inefficient state administration, corruption and selective use of repressive measures. This hybrid character of the political regime (Diamond 2002) creates a fertile ground for open protests which include acts of civil disobedience.

In 2010, in the 6 million strong Kyrgyzstan (out of which, according to unofficial data, more than 1 million had already emigrated) there were as many as 685 protests (583 rallies, 83 pickets, 15 roadblocks and 4 occupations of land). In 2011, that number had almost doubled to 1193 ( 680 rallies, 428 pickets, 18 marches, 16 demonstrations and 51 roadblocks). In 2012, high social mobilization continued with 1286 protests (537 rallies, 706 pickets, 4 marches, 2 demonstrations, 36 roadblocks and 1 occupation of land). 2012 was also the first year after the events of the April Revolution of 2010 that the authorities held 7 people criminally responsible for inciting violence against the state (including three members of parliament Kamchybek Tashiev, Talant Mamytov and Sadyr Japarov), while 97 people were fined or arrested for a short period of time in relation to their role in public protests (Исаев, 2014).

In the following years the number of protest decreased from 849 in 2013 to 434 in 2015 , although it again increased with the activation of a political struggle during the next presidential campaign. Compared to 596 protests in 2016, there were 188 protests in the capital alone in the first six months of 2017. Most of them focused on social and political issues, such as social injustice, abuse of power, negligence by authorities, or were confrontations between political forces (e.g. Omurbek Tekebaev, S. Japarow, Kanat Isaev, Omurbek Babanov, Bektur Asanov, Bekbolot Talgarbekov) (Исаев, 2014; Кыргыз, 2018, p. 118). However, all those actions were poorly organized and had little impact; they were short-lived, did not have a wider range, and usually consisted of one or two gatherings. They relied on existing organizational solutions and did not use any innovations.

Before the 2010 events, power in Kyrgyzstan had been concentrated in the hands of the President and his family. The president was presented as an embodiment of national interest, a leader who stood above the divisions of power. Personifying all the collective successes of the country, he was also seen as responsible for its problems. An obvious target of grievances and protests, the leader was targeted in popular slogans "Akaev ketsin" ("Akaev leave") or "Bakiev ketsin" ("Bakiev leave"). However, following the 
April Revolution of 2010, power was no longer concentrated in the hands of the president and his family. New alternative centers of power grew in importance. Some institutions were dissolved (e.g. Central Agency for Development, Investments and Innovations), some new ones emerged, and some have been given new powers (e.g. Jogorku Kenesh). This reshaping of formal and informal decision-making channels made it difficult for ordinary citizens to grasp the new political reality. It was now difficult to identify a single center of power toward which one could address claims and demands, with new potential targets of protest in the political system - courts, ministries, offices or presidential administration. In addition, the indifference of these institutions to the protests of citizens undermined an important element of collective action: trust in politics (conversations with Kyrgyz political actors, 2016-2018; Сагындык кызы, 2017).

Regime changes in Kyrgyzstan had a dramatic impact on other Central Asian countries. Recognizing the potential links between civil society, protest activity and regime change, the Kazakh and Uzbekistan authorities launched actions intended to prevent the emergence of similar forces in their local environments (Hale, 2005, 2006; Silitski, 2006; D’Anieri, 2006; Allison, 2008; Bader, Grävingholt, Kästner, 2010; Шукуралиева, 2018; Shukuralieva, 2018a, 2018b). They strengthened control over the activities of civil society organizations to narrow down the scope and structure of their abilities. Issues related to the functioning of the state, or those concerning the rights and freedoms of citizens, became the subject of securitization and were included in the extraordinary sphere of security (Buzan, Wæver, De Wilde, 1997). Citizens' requests for access to information, demands for revealing cases of corruption or abuse of power, and other forms of political activity, were now reinterpreted as an existential threat that deserved immediate action and emergency measures. Securitization provided an opportunity to legitimize various $a d$ hoc actions by authorities, such as restrictions on citizens' rights to exchange information, freedom of assembly, as well as the activities of commercial and religious organizations. These measures were accompanied by an expansion of law enforcement agencies.

In Kazakhstan, this involved measures such as the reactivation of repressive psychiatry (from about 2008), ${ }^{1}$ adoption of the Law on Religious Activities and Religious Associations (2011), ${ }^{2}$ the Act on National Security (2012), ${ }^{3}$ the Law on Trade Unions (2014), ${ }^{4}$ the Code of Administrative Offenses (2014), ${ }^{5}$ and amendments to the Law on Communication. ${ }^{6}$ The new laws restricted freedom of expression, freedom of association, collective bargaining, and gave authorities the right to block websites and social

${ }^{1}$ E.g. Zinaida Mukhortova, a known lawyer in Balkhash, was forcibly placed in psychiatric hospitals several times (for more details see: Казахстанское; Мухортова, 2011).

2 „Діни қызмет және діни бірлестіктер туралы” Қазақстан Республикасының 2011 жылғы 11 қазандағы № 483-IV Заңы.

3 “Қазақстан Республикасының ұлттық қауіпсіздігі туралы” Қазақстан Республикасының 2012 жылғы 6 қаңтардағы № 527-IV Заңы.

4 “Кәсіптік одақтар туралы” Қазақстан Республикасының 2014 жылғы 27 маусым дағы № 211-V Заңы.

5 “Әкімшілік құқық бұзушылық туралы” Қазақстан Республикасының 2014 жылғы 5 шілдедегі № 235-V Кодексі.

6 “Байланыс туралы” 2004 жылғы 5 шілдедегі № 567-II Қазақстан Республикасының Заңы. 
networks. In 2017 alone, approximately 9,000 websites were blocked in Kazakhstan (Аманбайқызы, 2018), including Facebook, YouTube, Google, and Foreignpolicy.com (Gussarova, 2018, p. 31-44). In almost all cases, state authorities denied permissions for peaceful demonstrations. ${ }^{7}$ Sanctions, such as fines or arrests of up to 15 days, were introduced for organizing or participating in marches, demonstrations, meetings or other public events which were not allowed by the authorities. ${ }^{8}$

The new measures reduced the number of peaceful protests. In 2011-2017, in the over 18 million Kazakhstan their number showed a clear downward trend, dropping from 162 to $36 .^{9}$ They were also increasingly short - in 2017 an average protest lasted only 15 minutes due to the swift action of the police (almost all of the protests were illegal due to the lack of permission from the authorities). Back in 2011-2014, rallies were organized mainly by the opposition and had a clear political tone. Relatively well-organized, they had a greater reach and usually were able elicit a serious reaction from the community. However, this was followed by a period of acute depoliticization. Peaceful demonstrations now focused on seemingly safe socio-economic demands, which could be observed in $60 \%$ of all protests in 2010, 91\% in 2011-2012, 99\% in 2012-2013, 84\% in 2016, 94.6\% in 2017 (Дуванов, 2018, p. 10-11). Scarce political protests used the slogan "Shal ket! ("Old man, get out"), demanding that 78-year-old President Nursultan Nazarbaev should resign. The slogan was sometimes used in musical and literary works published in the Internet, for example in the popular protest song "Shal ket" by Zhanat Yessentayev, a bard from Kazakhstan:

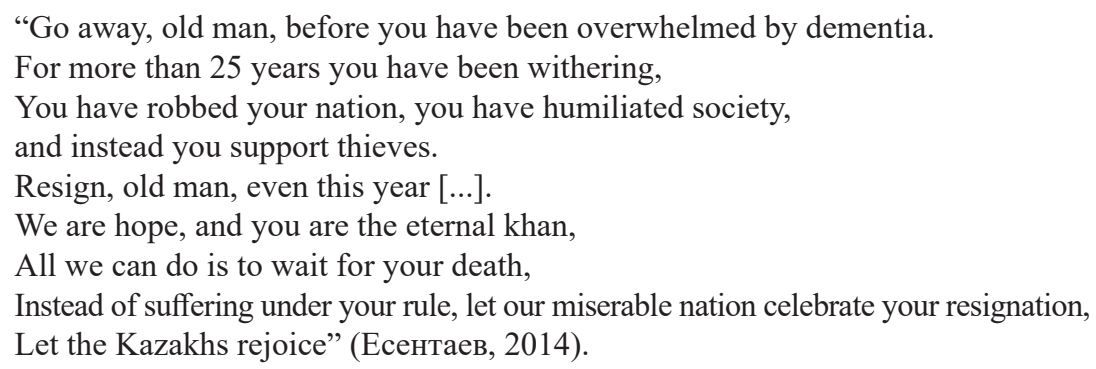

${ }^{7}$ In 2017, only 5 applications for a peaceful demonstration were granted permission by the state authorities. It was a march of support of the President of Kazakhstan; a picket against marriages of Kazakh women with Chinese; a meeting of the Nationwide Social Democratic Party (fake opposition party) against raising prices; the meeting of the owners of the business center " 7 th continent" in connection with their conflict with the bank; a one-man picket against "contradictory court judgements" (See: Астанадаzы; Перхальский, Фурсова, 2017; Пресс-релиз ОСДП, 2017; Дуванов, 2018, p. 20).

8 The authorities used a very vague interpretation of the term "peaceful assembly." These could be any action perceived as an act of protest, e.g. flash mob, flower laying, office meeting, joint petitioning, possession of a blue balloon (the color associated with the banned party Democratic Choice of Kazakhstan (DVK)), or blue clothes in a specific public space. Sometimes this lead to truly bizarre cases. In the city of Almaty, a woman who had announced and carried out a hunger strike at home was accused of breaching the law because she had not received permission from local authorities (See: field research, 2016, 2018; interviews with Kazakh political actors, 2016-2018; Zhovtis, 2014).

964 protests in 2010, 162 in 2011-September 2012, 119 in October 2012-September 2013, 114 in 2014, 71 in 2015, 52 in 2016, and 36 in 2017 (Дуванов, 2018, p. 10-11). 
The theme of Nazarbayev's age and duration of his reign (almost thirty years) were often mentioned in many informal conversations during fieldwork. Taxi drivers, shop and market vendors, public and private sector employees, pensioners and young people, talked about how tired they had become with their ruler. Nevertheless, any critique or act of opposition against the authorities altogether disappeared from the public space. Those parties, civil society organizations or individual activists who showed disloyalty to the ruling power and constituted a real force were removed from the political space. ${ }^{10}$ The majority of society was simply afraid of the consequences of publicly expressing any negative opinion towards the authorities or making political demands (fieldwork, 2016, 2018; Дуванов, 2018, p. 10-11).

The use of repressive measures undermined trust and influenced the individualization of social protests. About half of all peaceful rallies were the result of the spontaneous reaction of people who organized themselves on an ad hoc basis in relation to a specific issue. There was also an increase in the number of protests by individuals desperate to draw attention to their own problems. ${ }^{11}$ These protests, in reaction to their inability to overcome bureaucratic barriers, the bias of the judicial system, or social injustice, became an important means of public influence on the authorities. They increasingly often resorted to new forms of protest such as blockades of motorways, happenings, ${ }^{12}$ performances, chaining oneself e.g. to the fence of the prosecutor's office (Казахстанка пыталась) or the parliament (Глушкова, 2014), and going on hunger strikes. In most cases, however, they focused on narrowly understood self-interest or corporate interest, and did not raise issues which could be perceived as socially relevant. Not posing any real threat to the interests of individual officials and the political system, they were usually ignored by the prosecution and local authorities (Дуванов, 2018, p. 11).

Tajikistan is the only country in the region where the contestation of power turned into a five-year civil war (1992-1997). The 1997 armistice and agreement between the government (represented by the president Emomali Rahmon) and the United Tajik opposition (represented by the leader Said Abdulloh Nuri) was supposed to transform the armed conflict into an institutionalized political struggle. The representatives of the opposition were given a place in the government, a number of key positions in production plants, and their armed groups became part of the Tajikistan's army. However,

${ }^{10}$ This does not apply to political parties belonging to fake opposition, e.g. Communist People's Party of Kazakhstan, Ak Zhol Democratic Party, Nationwide Social Democratic Party.

${ }^{11}$ E.g. individual protests in 2016 accounted for 33\%; in 2017 - 36\% (Дуванов, 2018, p. 11).

${ }_{12}$ For example, in 2018, on the eve the national holiday Nowruz, the leader of the DVK party (banned in Kazakhstan for its supposed extremism), Mukhtar Ablyazov, used his YouTube channel to call on everyone who wanted to change the "Nursultan Nazarbaev regime" to go to the square with blue balloons. Blue was the color of the flag of Kazakhstan, but it was also the color of DVK. The police initially stopped people with balloons, but many of them were surprised to ask "is the symbol of Kazakhstan forbidden by national law?" Police officers also pulled the balloons out of the children's hands, to the astonishment of parents and witnesses. It was difficult to determine how many of those who held balloons were, in fact, supporters of the opposition, and how many of them simply celebrated Nowruz with their families. That action not only confused and discredited the authorities (as those grabbing children's balloons and spoiling the national holiday), but also promoted DVK (Seе: Аблязов, 2018; Putz, 2018; Глушкова, 2018). 
the agreement reached between the government and the opposition was quite volatile. Accusations against the authorities for violating the general agreement, restricting the functioning of the opposition, rigging elections and abusing power, lead to further armed conflicts which lasted until the end of 2000. In the following years, the protests against the consolidation of power by President Rahmon took the form of sabotage of government decisions, assassinations, guerrilla attacks and armed struggle. Yet the President succeeded at purging the political space of all forms of criticism. His opponents were killed, imprisoned, forced underground, and only a few managed to leave the country (Lewis, 2014; Marat, 2016).

Strengthened by reform and permission for violence, the law enforcement agencies became a powerful force ready to protect Rahmon's regime. Unlike in Kazakhstan, where the state made great efforts to institutionalize and legitimize repression, in Tajikistan violence was informal. The Tajik authorities have repeatedly denied blocking websites (e.g. Ozodagon, VKontakte, Facebook, YouTube, Google, Radio Free Europe/Radio Liberty), instant messaging (e.g. Viber, WhatsApp, Telegram), tracking the activities of Internet users, and eavesdropping on telephone conversations (International Partnership for Human Rights, 2018), blaming service providers instead. The latter admitted off the record that they received such instructions from the authorities (Tajikistan 2017). The surveillance of citizens also included the private sphere. Strict control involved all informal gatherings, such as birthday parties, weddings, or even funerals. ${ }^{13} \mathrm{~A}$ rich arsenal of non-judicial tools was used to punish those perceived as openly opposing the authorities. These measures included intimidation, dismissals, difficulties in accessing limited goods, etc. In winter 2018, Saida Rustamova, a teacher at the School of Choreography, was fired for not listening to the live broadcasting of President Rahmon's speech to the national parliament in the auditorium together with other employees of the school (В Таджикистане кониертмейстера). In 2017, in the Khuroson region, a small mistake in their performance by an amateur music band "Ochajonkho" ("Mommies") during the President's visit was treated as an act of protest and cost the head of the women's and family department her job (Карим, 2017). Peaceful assemblies which were not controlled by the authorities were very rare, and usually protested against the arbitrariness of law enforcement agencies or state institutions. The majority of society was apathetic and completely dependent on the whimsical administration (Matveeva, 2009; Tajikistan 2017; International Partnership for Human Rights, 2018).

Uzbekistan and Turkmenistan not only represented consolidated authoritarianism, but also had one of the most repressive systems in the world. The terror was aimed at intimidating the population and fighting real and alleged opponents of the regime. The

13 The public's reaction to the repressive nature of state policy is well illustrated by Tajikistan's 2009 opinion polls. About $80 \%$ of the respondents indicated that living conditions of an individual may only improve if he/she has good relations with the authorities. In addition, about $90 \%$ of respondents, including women and men, stated that they were neither members nor participants of any organizations, political parties, trade unions, professional associations, business or business associations, religious foundations, women's, civic, student or environmental associations. Not only did they not use any social networking sites, but even websites on sports, music, youth or other leisure activities. Moreover, about $90 \%$ of the respondents stated that they were not involved in any of the social networks that organize systematic meetings (sic!) (See: Сафаров, 2012, p. 83-86). 
countries were also widely militarized, with the prevailing atmosphere of denunciation and fear. The presidents of Uzbekistan Islom Karimov (1990-2016), Shavkat Mirziyoyev (from 2016) and Turkmenistan Gurbanguly Berdimuhamedow based their power on law enforcement agencies and the army. Their officers had good financing of their operations, had access to limited goods and received relatively high salaries. Maintenance of the national consensus was made possible by control of all areas of life. This also applied to difficulties in entering and leaving not only the country, but also individual regions. The restrictive migration policy required citizens to obtain a special permit to leave the country. However, obtaining an official authorization did not guarantee anything. At any time, without explaining the reasons, the authorities could cancel it, even if someone was already on a plane.$^{14}$ In the summer of 2018, the Turkmen authorities forbade people aged below 40 to leave the country (Türkmenistanda 40 ýaşyna). Slander and repression campaigns were not only directed against opponents, but also the members of their families. Some alleged oppositionists were forcibly treated in psychiatric hospitals (Amnesty International, 2005) ${ }^{15}$ and those less fortunate were sent to concentration camps. The Ovadan-depe in Turkmenistan and Jasliq in Uzbekistan earned the reputation of "death camps." In an interview for the BBC, the wife of one of the prisoners said: "When my husband was arrested, the local police told me that he had been sent to Jasliq and they added: don't wait for him to return home, we send people to Jasliq to die." 16

According to Jacek Tarkowski (1994, p. 38), years of mass repression, combined with effective control over all or most areas of social life, additionally isolated from external influences by the government's monopoly of information, can lead to social apathy. This is strongly associated with the perceived lack of an alternative. People cannot imagine a different reality or build a belief that the political, economic and social problems could be solved in a different way. Hence the widespread conviction that the prevailing order is not only natural, but also the only possible one. This is well illustrated by the following words: "when I lived in Turkmenistan, it all seemed normal to me" (conversation with

${ }^{14}$ After President Shavkat Mirziyoyev came to power in December 2016 in Uzbekistan, the system was relaxed. Some political prisoners were released. Control over the functioning of the press and NGOs weakened, and the institution of 'exit visas' is to be withdrawn in 2019.

${ }^{15}$ For example, a journalist and nephew of the President of Uzbekistan Islom Karimov, Jamshid Karimov was forcibly hospitalized in a psychiatric hospital for open criticism of the authorities in 20062017; the same happened to Elena Urlaeva, chairperson of the Human Rights Alliance of Uzbekistan in 2001, 2002, 2005, 2012 and 2016, and Sanjar Umarov in 2005. According to Jamshid Karimov, almost all dissidents in Uzbekistan were held by force in psychiatric hospitals for at least 2-3 month (See: Кирилллова, 2018; Uzbekistan. Country Reports; Interview with Jamshid Karimov).

16 Jasliq prison (codename UYA 64/71), also known as the "death camp", was built in 1999 in the most remote and deserted corner of the north-western part of Uzbekistan. This region is also known for its harsh climate; in summer the air temperature rises above $+50^{\circ} \mathrm{C}$, and in winter it drops below $-20^{\circ} \mathrm{C}$. It was the prison for people considered to be the most dangerous opponents of the regime, including those accused of attempting to overthrow the constitutional system and for membership in forbidden organizations. Jasliq prison was famous for its particularly brutal torture. The most publicized case was the death of two prisoners in 2002: Husnidin Alimov and Muzafar Avazov. According to doctors' conclusions, their death was violent. About $60-70 \%$ of their bodies were submerged in boiling water. In addition, Avazov had a bloody wound on his head and extensive bruises on his forehead and neck; he was also deprived of his nails. (See e.g.: Наджибулла, 2012; Аскаров, 2003; Bukharbaeva, 2005; Human Rights Watch, 2002, 2004). 
a former Turkmen citizen, 2016). However, escapes by opposition politicians, journalists, poets and activists from the country, study and work trips, and increasingly easy access to new technologies did create a new opposition to the hard authoritarian regimes.

The virtual world gave hope, not only of expressing one's own opinion, but also in accessing uncensored information, revealing the truth and seeking justice. People who for various reasons were outside Uzbekistan and Turkmenistan set up dozens of websites, channels and video blogs on YouTube (e.g. turkmenyurt.tv, www.hronikatm.com, habartm.org, huquqbon3.wordpress.com, uznews.net, muhammadsalih.com, videoblog Abdujalil Boymatov), and were also active on social networks. Most of them focused on criticism of the government. They published materials documenting violence, including photographs, videos, handwritten letters, poems, statements, speeches, and interviews with witnesses and victims. Condemning the government, they pointed to the lawlessness of the security forces, the ruthlessness of the administration, the conspicuous consumption of luxury goods of the ruling elite, ${ }^{17}$ in a situation where the rest of the society lived in terrible poverty and was regularly forced to harvest cotton with no remuneration.

Having no possibility to organize direct actions aimed at changing the political system in their homelands, exiled activists are able to undermine the hegemony of government propaganda in the Internet. Importantly, that Internet-based opposition is not completely separated from the inhabitants of Turkmenistan and Uzbekistan. Local Internet users, despite the restrictive government policy and problems with electricity, found the means to bypass the Internet locks. They accessed websites blocked in the country, using Google search engine, the social network Odnoklassniki, or by using tools to protect privacy and anonymity, e.g. proxy servers, VPN, or The Onion Router. Nevertheless, it is worth noting that the Internet is relatively expensive and its quality is very poor (See е.g.: Альтернативные, 2018а; Хатамов, 2018).

Thanks to this mutual, though of course not easy, interaction between exiled activists and people in the country, the Internet websites became a platform for building a narrative radically different from government propaganda. Here, they were able to point to possible alternatives (conversations with Uzbek political actors, 2016-2018). For example, a videoblog by Kudrat Babadjanov (Бабаджанов, 2013, 2014a, 2014b, 2016) explains why the Uzbek society (including children, teachers, doctors, cultural and scientific workers) should not harvest cotton as forced laborers, a practice dating back the times of the Soviet Union, and still used in the present Uzbekistan. He also underlines the power of online petitions: "Although it will not produce immediate results, such documents are an effective tool of pressure that can gradually change the world." (2014a). He gives an example of how such petitions contributed to the overthrowing of Viktor Yanukovych's government in Ukraine in 2013-2014. He also provides guidance on how to prepare, distribute and sign them correctly. Geldi Kyarizow (2018), a political prisoner, one of the few who returned from the Ovadan-depe camp, speaks to the Turkmen, calling on the people to unite, regain

${ }^{17}$ The son-in-law of Turkmen President Gurbanguly Berdimuhamedow, 28-year-old Ebubekir Bekdurdiyew, boasted of a luxurious life on his profile on the Russian social network site "VKontakte." Yachts, casinos, travels around the world and a passion for luxury watches, such as Richard Mille RM011 Felipe Massa Bout Edition for 200,000 USD, or Richard Mille Tourbillon 52-02 Horse produced in a limited edition for Qatar for 565,000 USD. According to the calculations of the Alternative News of Turkmenistan (Альтернативные, 2018b) all his watches cost more than \$1 million. 
their subjectivity and fight against the regime. He recalls the models of peaceful revolutions in Georgia (2003) and Armenia (2018), where a change of power took place. He explains in detail the potential role of people who come back from the prisons, as well as doctors, teachers, high-ranking officials or shepherds - everyone who wants to regain dignity and freedom. However, the Internet rebellion against dictatorships has as yet failed to give tangible results. The political systems of Turkmenistan and Uzbekistan continue unabated. Nevertheless, the virtual community has succeeded in undermining the much stronger government narrative, proposing a new idea that it would be morally correct and fair to change the existing socio-political order.

\section{Conclusions}

The survival of authoritarian regimes is often analyzed from a top-down perspective, as the effect of the ability of the authorities to deliver certain goods, use violence, apathy, legitimacy, or a combination of the above factors. It is worth emphasizing, however, the importance of the authorities' reactions to the grassroots protests in determining the range and form of action for opposition or protest movements. The number of protests and other collective actions in the hybrid system in Kyrgyzstan were much higher than in the hard authoritarian regimes in Central Asia. The experiences of the opposition activists in the latter support the arguments of those authors who point to the importance of modern communication technologies in the processes of information, mobilization and recruitment. By lowering operating costs, deterritorializing, and ensuring anonymity, Internet activities make it possible to formulate a critique that would otherwise be impossible under severe repression.

\section{Bibliography}

\section{Articles and books:}

Allison R. (2008), Virtual regionalism, regional structures and regime security in Central Asia, "Central Asian Survey", vol. 27, no. 2.

Amnesty International (2005), Turkmenistan: The clampdown on dissent and religious freedom continues, 2.05.2005, Index number: EUR 61/003/2005.

Bader J., Grävingholt J., Kästner A. (2010), Would autocracies promote autocracy? A political economy perspective on regime-type export in regional neighbourhoods, "Contemporary Politics", vol. 16 , no. 1.

Bukharbaeva G. (2005), Uzbek Prison Brutality, Institute for War \& Peace Reporting, RCA Issue 200, 21.02.2005.

Buzan B., Wæver O., De Wilde J. (1997), Security: A New Framework for Analysis, Lynne Rienner Publishers, London.

D'Anieri P. (2006), Explaining the success and failure of post-communist revolutions, "Communist and PostCommunist Studies", vol. 39, no. 3.

Diamond L. (2002), Thinking About Hybrid Regimes, "Journal of Democracy”, vol. 13, no. 2.

Freedom House (2018a), Populists and Autocrats: The Dual Threat to Global Democracy. Freedom in the World 2017. 
Freedom House (2018b), The Rise of Digital Authoritarianism. Freedom on the Net 2018, New York 10.2018 .

Freedom House (2018c), Freedom of the Press 2017. Table of Country Scores.

Goldstone J., Tilly C. (2001), Threat (And Opportunity): Popular Action and State Response in the Dynamics of Contentious Action, in: Silence and Voice in the Study of Contentious Politics, eds. R. Aminzade, J. Goldstone, D. Mcadam, E. Perry, W. Sewell, S. Tarrow, et al., Cambridge University Press.

Gussarova A. (2018), Countering Extremism vs. Freedom of Online Expression: The Case of Kazakhstan, in: New Voices from Central Asia: Political, Economic, and Societal Challenges and Opportunities, vol. 2, ed. M. Laruelle, The George Washington University, Washington.

Hale H. E. (2005), Regime cycles: democracy, autocracy, and revolution in post-Soviet Eurasia, "World Politics", vol. 58.

Hale H. E. (2006), Democracy or autocracy on the march? The coloured revolutions as normal dynamics of patronal presidentialism, "Communist and Post-Communist Studies", vol. 39.

Human Rights Watch (2002), Uzbekistan: Two Brutal Deaths in Custody. Deaths Reveal "Horror" of Uzbek Prisons, 09.08.2002.

Human Rights Watch (2004), Creating Enemies of the State. Religious Persecution in Uzbekistan, Washington.

International Partnership for Human Rights (2018), The Danger of Standing up for Justice and Rights in Central Asia. Trends regarding the Protection of Civil Society in the Region in 2017, Brussels 03.2018.

Lewis D. (2014), Crime, terror and the state in Central Asia, "Global Crime", vol. 15, no. 3-4.

Marat E. (2016), Post-violence regime survival and expansion in Kazakhstan and Tajikistan, "Central Asian Survey", vol. 35, no. 4.

Matveeva A. (2009), Tajikistan: Revolutionary situation or a Resilient state?, EUCAM Policy Brief no. 12.

Meyer D. S. (2004), Protest and political opportunities, “Annual Review of Sociology”, t. 30.

Putz C. (2018), Ablyazov's Balloons: Kazakh Opposition Co-opts the Color Blue, "The Diplomat", 27.03.2018.

Scott J. C. (1987), Weapons of the Weak. Everyday Forms of Peasant Resistance, Yale University Press.

Shukuralieva N. (2018a), Azja Centralna: uwarunkowania bezpieczeństwa regionalnego, "Środkowoeuropejskie Studia Polityczne", Wydział Nauk Politycznych i Dziennikarstwa Uniwersytetu im. Adama Mickiewicza w Poznaniu, no. 2.

Shukuralieva N. (2018b), Azja Centralna: uwarunkowania integracji regionalnej, in: Relacje Unii Europejskiej z Azja Centralna. Uwarunkowania, wyzwania, efekty, eds. T. Wallas, R. Fiedler, FNCE, Poznań.

Silitski V. (2006), Contagion Deterred: Preemptive Authoritarianism in the Former Soviet Union (the Case of Belarus), CDDRL Working Papers, Stanford University, no. 66.

Tajikistan 2017 Human Rights Report. Executive Summary, U.S. State Department, Bureau of Democracy, Human Rights, and Labor, 2018.

Tarkowski J. (1994), Legitymizacja władzy. Zagadnienia teoretyczne i opinie oficjalne, in: J. Tarkowski, Socjologia świata polityki, tom 1: Władza i społeczeństwo w systemie autorytarnym, eds. P. Marciniak, E. Tarkowska, ISP PAN, Warszawa.

Tilly Ch. (2006), Regimes and repertoires, The University of Chicago Press.

Uzbekistan. Country Reports on Human Rights Practices for 2016, U.S. State Department, Bureau of Democracy, Human Rights, and Labor, 5.04.2017. 
Van De Donk W. B., Loader B. D., Nixon P. G., Rucht D. (2004), Introduction: social movements and ICTs, in: Cyberprotest: New Media, Citizens, and Social Movements, eds. W. van de Donk, B. Loader, P. Nixon, D. Rucht, Routledge, New York.

Сафаров С. (2012), Отчуждение от участия в политической жизни как процесс и как результат, in: Проблемы социального отчуждения и развитие человеческого потенциала Республики Таджикистан: коллективная монография, еd. Р. М. Бабаджанов, ООО “Фарзин 2012”, Душанбе.

Шукуралиева Н. (2018), Демократическая самоорганизачия. Мобилизачия во время "иветных революиий”, "Studia Politologiczne”, Instytut Nauk Politycznych Uniwersytetu Warszawskiego, vol. 48.

\section{Sources:}

Interview with Jamshid Karimov, Videoblog by Abdujalil Boymatov, 21.08.2017, https://www.youtube.com/watch?v=bsZTohUF1hM.

Kyarizow G. (2018), Speech. Turkmenistan: the struggle of the people with haramdag Berdimuhamedow's dictatorship, 29.06.2018, https://www.youtube.com/watch?v=K8_ZIYdc1-w.

NGO Kazakhstan International Bureau For Human Rights and Rule Of Law, bureau.kz, 01.11.2018.

Türkmenistanda 40 ýaşyna ýetmedikler ýurdun̆ daşyna çykarylmaýar, 27.06.2018, https://www.azathabar.com/a/29323368.html.

Zhovtis Y. (2014), Address at the session of the OSCE Office for Democratic Institutions and Human Rights in Warsaw, 24.09.2014.

“Байланыс туралы” 2004 жылғы 5 шілдедегі № 567-II Қазақстан Республикасының Заңы.

“Діни қызмет және діни бірлестіктер туралы” Қазақстан Республикасының 2011 жылғы 11 қазандағы № 483-IV Заңы.

“Әкімшілік құқық бұзушылық туралы” Қазақстан Республикасының 2014 жылғы 5 шілдедегі № 235-V Кодексі.

“Кәсіптік одақтар туралы” Қазақстан Республикасының 2014 жылғы 27 маусым дағы № 211-V Заңы.

“Қазақстан Республикасының ұлттық қауіпсіздігі туралы” Қазақстан Республикасының 2012 жылғы 6 қаңтардағы № 527-IV Заңы.

Аблязов М. (2018), Наурыз 2018!, 20.03.2018, https://www.youtube.com/watch?v=BHs_8jitISY\& feature=youtu.be.

Альтернативные Новости Туркменистана (2018a), Интернет в Туркменистане: Сеть расширяется, а связь все хуже, 15.01.2018, https://habartm.org/archives/8361.

Альтернативные новости Туркменистана (2018b), Туркменистан: Откуда у зятя Гурбангуль Бердымухамедова часов на 1 миллион долларов?, 6.02.2018, https://www.youtube.com/ watch? $=\mathrm{AW} 3 \mathrm{M}-\mathrm{FtXngI}$.

Аманбайқызы Ж. (2018), Терроризмді насихаттайтын 9 мыңза жуық сайт бұватталды, 16.02.2018, http://kazaknews.kz/okiga/about-9000-sites-that-promote-terrorism-have-beenblocked/.

Аскаров У. (2003), Суровое лето в Жасльке, 12.06.2003, http://news.bbc.co.uk/hi/russian/news/ newsid_2983000/2983382.stm.

Астанадавы митингке құатысушылар мәселелерін шешуде бас прокурор мен президенттен көмек сұрап отыр, Sputnik 14.02.2017, https://sputniknews.kz/incidents/20170214/1578164. html.

Бабаджанов К. (2013), Ўзбекистонда болалар қуллиги туххтатилсин! 1.06.2013, https://www. youtube.com/watch?v=PtZ58R5NjY4.

Бабаджанов К. (2014a), Петиции в Интернете: как это работает, 09.02.2014, https://www.youtube.com/watch?v=k9tVQeur3Tw. 
Бабаджанов К. (2014b), Почему я должен собирать хлопок? 24.09.2014, https://www.youtube. $\mathrm{com} /$ watch?v=FIoLH6i0YIU.

Бабаджанов К. (2016), Тошкент синдроми, 6.07.2016, https://www.youtube.com/watch?v= r8qkwBL6zd8.

В Таджикистане кониертмейстера уволили за отказ послушать послание президента, "Радио Озоди", 14.02.2018.

Глушкова С. (2014), Акиию протеста против изъятия земель “под госнужды” " разогнали, “Радио Азаттык”, 15.04.2014.

Глушкова С. (2018), Астанада көк шармен жүрген бірнеше адамды полииия ұстады, “Азаттық радиосы”, 22.03.2018.

Дуванов С. (2018), Отчет о результатах мониторинга реализации права казахстаниев на мирные собрания в 2017 году, Алматы.

Есентаев Ж. (2014), Шал кет, 15.02.2014, https:/www.youtube.com/watch?v=qD1NpjF3Sdk.

Исаев А. (2014), Кыргызстан бузящий, “Дело №...”, 17.04.2014.

Казахстанка пыталась приковать себя к забору Генпрокуратуры РК, “Караван”, 17.09.2015.

Казахстанское Международное бюро по правам человека и соблюдению законности, https:// bureau.kz/search/, 11.11.2018.

Карим О. (2017), “Плохо били в бубен”, или как в Хуросоне местная чиновница лишилась карьеры, “Радио Озоди”, 14.08.2017.

Кириллова К. (2018), Карательная психиатрия для неугодных: как в Узбекистане борются с инакомыслящиими, https://ru.krymr.com/a/uzbekistan-punitive-psychiatry/29400477.html, 31.07.2018.

Кожекова А. (2017), Правозащитные организации требуют снять запрет на въезд в Кыргызстан Пономареву, 14.07.2017, 24.kg/obschestvo/57535/.

Кыргыз Республикасынын Акыйкатчысынын (Омбудсменинин) баяндамасы. 2017-жыль Кыргыз Республикасында адамдын жана жарандын укуктары менен эркиндиктеринин сакталышы жөнүндө, Бишкек: Q-Print 2018.

Мухортова 3. (2011), Videoblog. Казахстан: карательная психиатрия в действии, 6.11.2011, https://www.youtube.com/watch?time_continue $=65 \& \mathrm{v}=\mathrm{kh}-\mathrm{qcyZrUAU}$.

Наджибулла Ф. (2012), Өзбекстанның “барса келмеске” айналван түрмесі, “Азаттық радиосы”, 03.08.2012.

Перхальский С., Фурсова И. (2017), Есть ли вообще правосудие в Казахстане?, 25.12.2017, http://www.gorodpavlodar.kz/News_57902_4.html.

Пресс-релиз ОСДП (2017), За твою достойную жизнь, Семей 21.10.2017.

Сагындык кызы Э. (2017), Кыргызстан: Анатомия митингов, 17.04.2017, https://cabar.asia/ru/ kyrgyzstan-anatomiya-mitingov/.

Хатамов А. (2018), Друг Аркадаг интернету или враг?, “Альтернативные Новости Туркменистана", 06.04.2018, https://habartm.org/archives/8877.

\section{Interviews:}

Conversations with a former Turkmen citizen, 2016.

Conversations with Kazakh political actors, 2016-2018.

Conversations with Kyrgyz political actors, 2016-2018.

Conversations with Uzbek political actors, 2016-2018.

Field research in Kazakhstan, 2016, 2018. 


\section{"My jesteśmy nadzieją, ty wiecznym chanem". Reżimy autorytarne i możliwości kontestacji w Azji Centralnej}

\section{Streszczenie}

Celem niniejszego tekstu jest analiza politycznych uwarunkowań funkcjonowania opozycji oraz praktyk kontestacyjnych w reżimach niedemokratycznych Azji Centralnej. Oparcie analizy na pięciu krajach o zróżnicowanym nasileniu autorytaryzmu pozwala prześledzić zależności pomiędzy kontekstem politycznym i działaniami protestacyjnymi, które w różnej, uwarunkowanej strukturą władzy, formie występowały we wszystkich pięciu krajach regionu. Artykuł, posługując się przykładem krajów Azji Centralnej, dostarcza empirycznej dokumentacji pomysłów o istnieniu wzajemnej zależności między repertuarami kontestacji a typami reżimu politycznego. Ponadto eksponuje on rolę aktywizmu internetowego w informowaniu, mobilizowaniu opinii publicznej, skłanianiu do wyrażania opinii, gromadzeniu różnych zasobów, prowokowaniu poparcia oraz budowaniu sieci relacji w ramach społeczeństwa obywatelskiego. Wreszcie, jak wskazuje niniejszy tekst, im większy poziom represyjności reżimu, tym mniej możliwości użycia tradycyjnych form kontestacji, a w skrajnych przypadkach kontestacja ogranicza się do przestrzeni online.

Słowa kluczowe: Azja Centralna, autorytaryzm, protest, kontestacja, represja, opozycja 
